\title{
Multiple congenital defects in a newborn foal
}

[Defeitos congênitos múltiplos em um potro recém-nascido]

\author{
J.F. Silva, R. Serakides, S.A. França, J.N. Boeloni, N.M. Ocarino*
}

Escola de Veterinária - Universidade Federal de Minas Gerais - UFMG - Belo Horizonte, MG

\begin{abstract}
A case of multiple congenital defects in a newborn foal is reported. The animal showed hypoplasia of the left pelvic limb bones, uterus unicornis, congenital diaphragmatic hernia, and unilateral renal and ureteral agenesis. This report includes the macroscopic and microscopic lesions observed in the case.
\end{abstract}

Keywords: foal, congenital defects, uterus, kidney, diaphragm

\section{RESUMO}

Relata-se um caso de defeitos congênitos múltiplos em um potro recém-nascido. O animal apresentou hipoplasia dos ossos do membro pélvico esquerdo, útero unicorno, hérnia diafragmática congênita e agenesia renal e ureteral unilateral. Este relato inclui as lesões macroscópicas e microscópicas observadas no caso.

Palavras-chave: potro, defeitos congênitos, útero, rim, diafragma

\section{INTRODUCTION}

Congenital defects are structural or functional malformations arising from errors during fetal development that can modify an isolated portion of a body system, the complete system or parts of several systems (Noden and Lahunta, 1985). These malformations are rarely observed in equines but when they do occur there are multiple congenital malformations (Crowe and Swerczek, 1985). In the literature, eight anomalies were identified as the most frequent in equines, including cryptorchidism, umbilical hernia, contracted tendons, and dislocation of the patella (Crowe and Swerczek, 1985). However, uterus unicornis, congenital diaphragmatic hernia, unilateral renal and ureteral agenesis are rarely reported in equines (Waldridge et al., 2009; Sabev and Kanakov, 2009; Romero and Rodgerson, 2010).

This report describes one case of multiple congenital defects in a newborn foal.

\section{CASUISTRY}

A newborn female Quarter Horse foal with parents of high zootechnical value was submitted to necropsy at the Veterinary Hospital School of Universidade Federal de Minas Gerais with a history of perinatal death and malformation of the left pelvic limb.

Necropsy and X-ray imaging revealed incomplete development of the left calcaneus, tarsal, metatarsal and phalanges (Figure 1A and B). In the abdominal cavity, the muscular portion of the dorsal left hemidiaphragm near the aortic hiatus, was a opening congenita with dimensions of $3 \times 5 \times 7 \mathrm{~cm}$ (Figure 2A) in which multiple organs, including the spleen, liver, stomach and small intestines, insinuated into the thoracic cavity. The left kidney and ureter were absent, and residual renal tissue was not identified, characteristic of unilateral renal and ureteral agenesis (Figure 3). The right kidney, ureter and urinary bladder were normal. The left uterine horn and oviduct were absent, characteristic of uterus unicornis (Figure 3). The right and left gonads were present (Figure 3 ). In the thoracic cavity, the left lung showed intense volume reduction and appeared dark red and flaccid, consistent with atelectasis (Figure 2B). The other organs of the thoracic and abdominal cavities showed no macroscopic changes.

Recebido em 17 de maio de 2013

Aceito em 30 de julho de 2014

*Autor para correspondência (corresponding author)

E-mail: nataliaocarino@gmail.com 

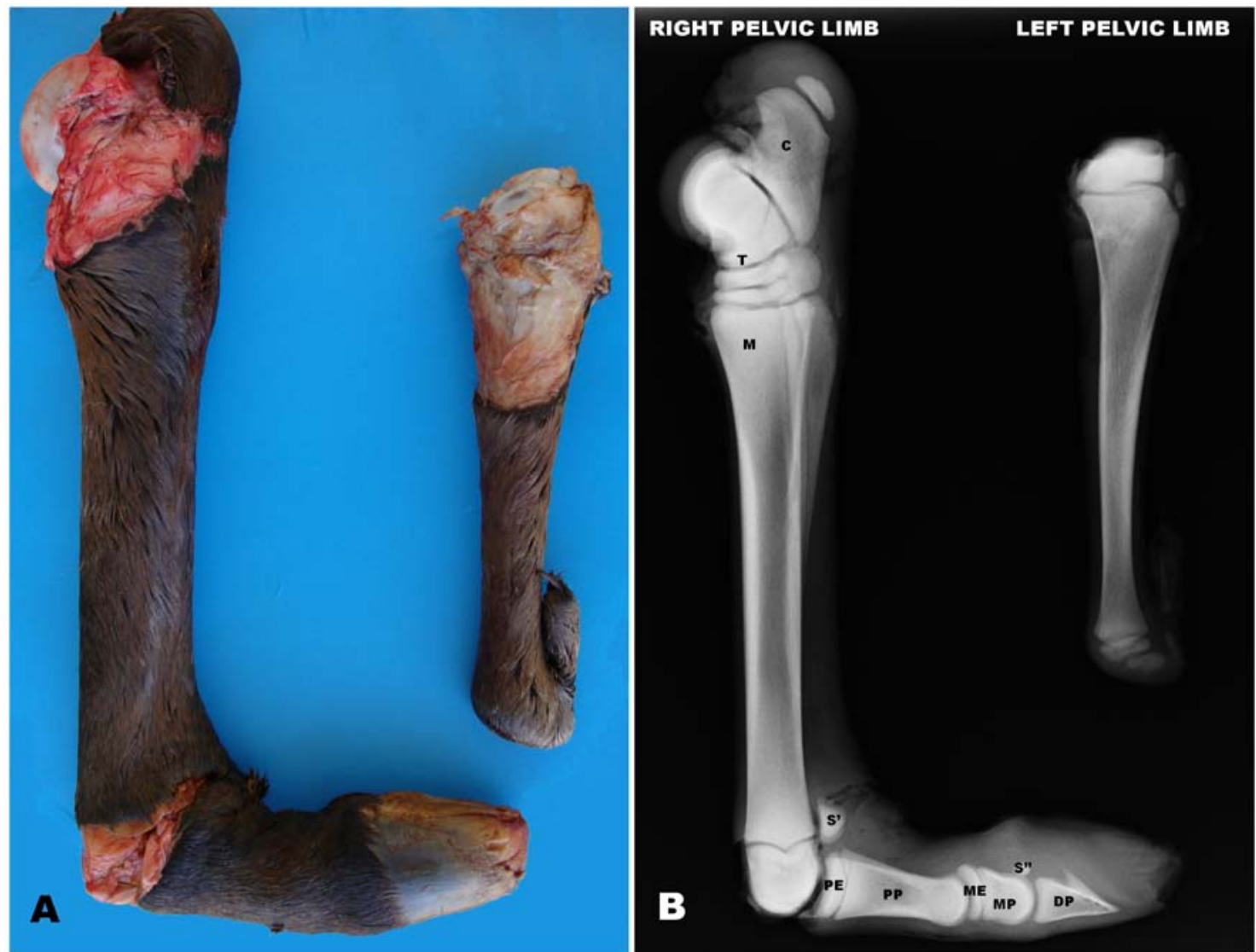

Figure 1. Multiple congenital defects in a newborn foal.Necropsy (A) and X-ray (B) show the incomplete development of the left calcaneus, tarsal, metatarsal and phalanges. (C-calcaneus; T- tarsal; Mmetatarsal; EP-epiphysis of the proximal phalange; PP- proximal phalange; ME- epiphysis of the media phalange; MP- media phalange; DP-distal phalange; S’ and S”- sesamoid).

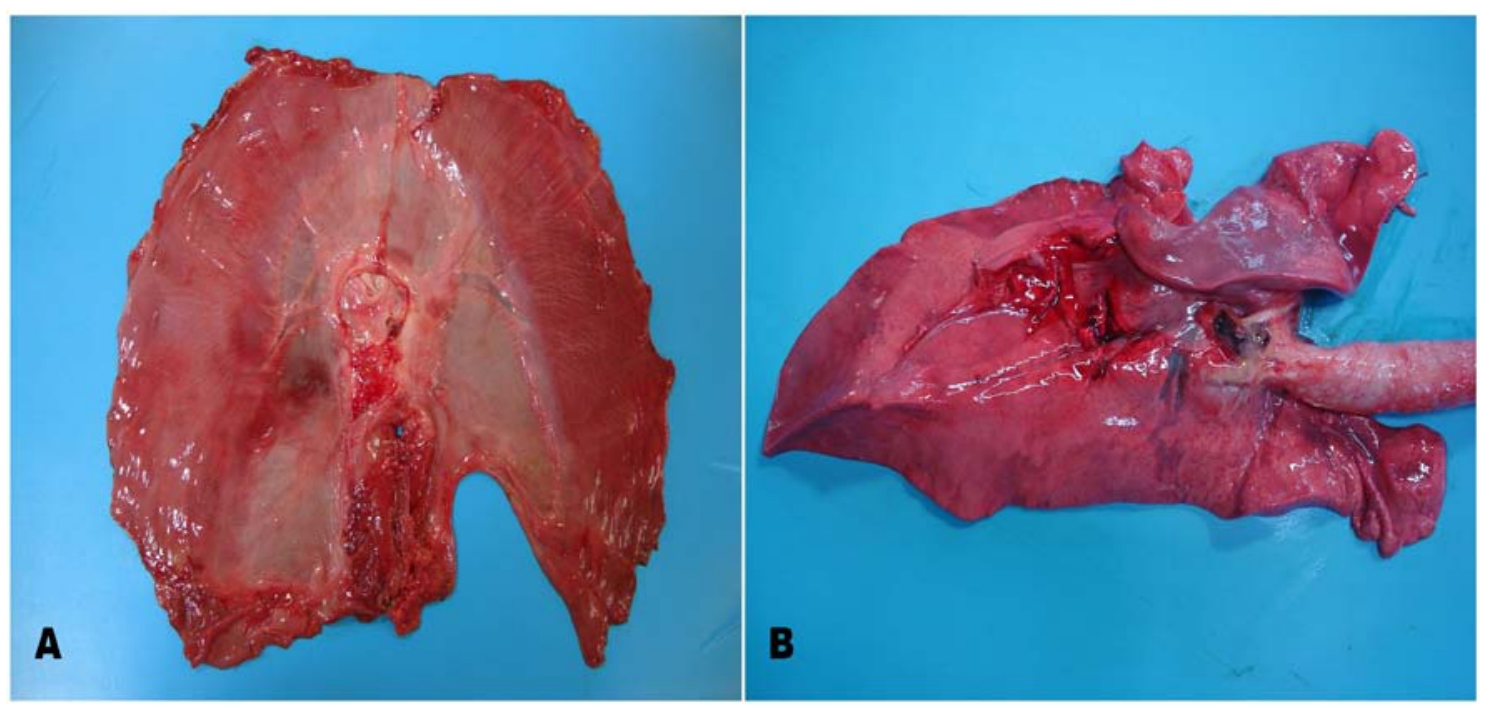

Figure 2. Multiple congenital defects in a newborn foal. A) Hemidiaphragm with opening congenita. B) Left lung with extreme volume reduction, a dark red appearance, and a flaccid consistency characteristic of atelectasis. 


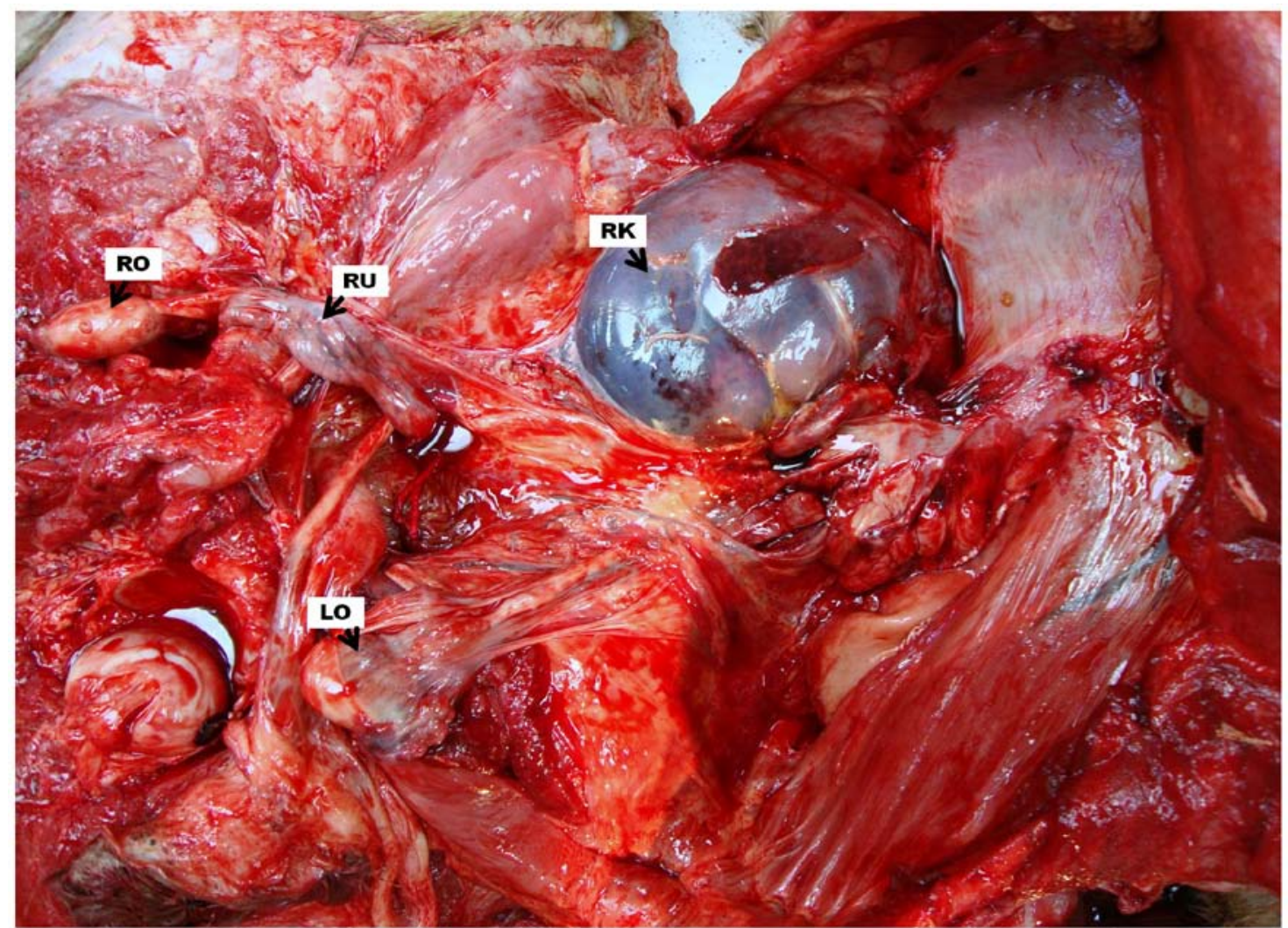

Figure 3. Multiple congenital defects in a newborn foal. The left kidney, left ureter, left uterine horn, and oviduct were absent.

Fragments of the lungs, right kidney, diaphragm, gonads, right uterine horn, right and left pelvic limbs, and other organs were fixed in $10 \%$ neutral phosphate-buffered formalin. The bones (tarsal, metatarsal and phalanges) of the affected and normal pelvic limbs were fixed in $10 \%$ buffered formalin and demineralized in a $10 \%$ formic acid solution at $\mathrm{pH} 4.5$ for one month. The bones and soft tissue were embedded in paraffin, cut into $5 \mu \mathrm{m}$ thick sections, and stained with hematoxylin and eosin for morphological analysis.

Microscopically, the left lung showed intense and diffuse collapse of the alveolar septa, while the right lung was histologically normal. Both gonads were poorly differentiated, with eosinophilic interstitial cells flowing and the presence of fibrous stromal tissue with few follicular structures consistent with primordial and primary follicles. The diaphragm had a focally extensive fibrous tissue associated with well-differentiated small blood vessels. The metatarsal, although lower on the limb, was the only bone of the affected pelvic limb that had distinct epiphyses, epiphyseal plate, metaphysis and diaphysis. As in the normal limb, the cortical was formed by trabecular bone. In other bones of the affected pelvic limb, cartilage was observed in the periphery with central trabecular bone tissue, similar to one ossification center without distinction between epiphyseal plate and articular cartilage. Other organs were histologically normal.

Based on macroscopic and microscopic findings, the diagnosis of multiple congenital malformations in the foal was confirmed.

\section{DISCUSSION}

Congenital malformations are uncommon pathologies in domestic species, especially horses (Crowe and Swerczek, 1985). When they do occur, the urogenital and musculoskeletal systems are most frequently affected (Priester et al., 1970). In horses, the presence of multiple congenital malformations is rare and has been 
infrequently reported in the equine literature (Crowe and Swerczek, 1985; Waldridge et al., 2009). Many factors have been described as causes of congenital defects, such as genetic defects, exposure to exogenous teratogenic substances, infections, and trauma (Crowe and Swerczek, 1985), but many have an unknown etiology. In this case, the history reported by the owner of the mare did not mention the occurrence of trauma, infectious diseases or use of teratogenic substances. Consanguinity was discarded as a potential cause as the property was breeding the animals for high zootechnical value with tight control of paternity. Trauma was also eliminated as a cause of death due to the necropsy findings.

Congenital skeletal malformations, including amelia, hemimelia and adactylia, have been described in horses (Leme et al., 2003; DeBowesand Leipold, 1984). In this foal, all of the left pelvic limb bones were formed but had undergone incomplete development.

Renal and ureteral agenesis characterized by the absence of the formation of the kidney and the ureter is also uncommon in horses (Waldridge et al., 2009). The absenceof the left kidney andureter indicates a failure of the left ureteric bud in the developing mesonephric duct and the subsequent failure to induce differentiation of the metanephricblastemaon the left side (Graves, 2003; Waldridge et al., 2009). Interestingly, renal agenesisisusually associated with abnormalities of the ipsilateral reproductive system (McEntee, 1990; Graves, 2003), which can be seen in this case as uterus unicornis. The association between renal agenesis and uterus unicornis can be explained by the fact that the uterus and part of the kidney develop from the esonephros (McEntee, 1990). In this case, the ovaries may not have been affected because of the differing embryological origin from the uterine horn, i.e., the gonadalridge (McGeady, 2006).

The diaphragmatic hernia found in the foal in this case was likely congenital, as in this and all herniation cases previously reported in horses, the borders were smooth, fibrous and thickened in a congenital hernia (Sabev and Kanakov, 2009; Romero and Rodgerson, 2010). Furthermore, because the margins of the hernia had no recent signs of bleeding or inflammation, the hernia was not traumatic in origin. In horses, defects of the diaphragm occur in $2.3 \%$ of the population (Crowe and Swerczek, 1985). Embryologically, the diaphragm is formed by the transverse septum, the dorsal mesentery, the pleuroperitoneal folds and the mesenchymal body wall (Pauwels et al., 2007). Diaphragmatic hernias, particularly retroesternais, develop when the septum transversum and pleuroperitoneal folds do not fuse completely (Pauwels et al., 2007). The lack of fusion results in a defect in the diaphragm muscle that develops later in the hernia sac. The hernia sac is as much peritoneum as it is the pleura (Pauwels et al., 2007).

The foal's death was the result of the compression of the lungs and heart by the abdominal organs, which compromised cardiorespiratory function, particularly evidenced by complete atelectasis of the left lung.

\section{ACKNOWLEDGEMENTS}

This work was supported by grants from Próreitoria de Pesquisa da Universidade Federal de Minas Gerais (PRPq/UFMG).

\section{REFERENCES}

CROWE, M.W.; SWERCZEK, T.W. Equine congenital defects. Am. J. Vet.Res., v.46, p.353358,1985.

DEBOWES, R.M.; LEIPOLD, H.W. Anterior Amelia. J. Equine Vet.Sci., v.4, p.133-135, 1984.

GRAVES, E.A. Congenital disorders of the urinary tract. In: ROBINSON, N.E., SAUNDERS, W.B. (Ed). Current Therapy in Equine Medicine. St. Louis: SAUNDERS ELSEVIER, 2003. p.826-828.

LEME, M.C.M.; MARTINS, A.M.C.R.F.; PORTUGAL, M.A.S.C. Ocorrência de Abraquia em um Potro - Relato de Caso. Arq. Inst. Biol., v.70, p.213-214, 2003.

MCENTEE, K. (Ed). Reproductive Pathology of Domestic Mammals. San Diego: ACADEMIC PRESS, 1990. 401p.

MCGEADY, T.A.; QUINN, P.J.; FITZPATRICK, E.S. et al. (Ed). Veterinary Embryology. Oxford: BLACKWELL PUBLISHING, 2006. 377p. 
NODEN, D.M.; LAHUNTA, A.D.E. (Ed) The Embryology of Domestic Animals. Baltimore: WILLIAMS and WILKINS, 1985. 367p.

PAUWELS, F.F.; HAWKINS, J.F.; MACHARG, M.A. et al. Congenital retrosternal (Morgagni) diaphragmatic hérnias in three horses. J. Am. Vet. Med. Assoc., v.231, p.427-432, 2007.

PRIESTER, W.A.; GLASS, A.G.; WAGGONER, N.S. Congenital defects in domesticated animals: General considerations. Am. J. Vet. Res., v.31, p.1871-1879, 1970.

ROMERO, A.E.; RODGERSON, D.H. Diaphragmatic herniation in the horse: 31 cases from 2001-2006. Can. Vet. J., v.51, p.12471250, 2010.
SABEV, S.P.; KANAKOV, D.T. Diaphragmatic hernia in a horse - a case report. Vet. Archiv., v.79, p.97-103, 2009.

WALDRIDGE, B.M.; LENZ, S.D.; HUDSON, J.; RODRIGUEZ-HURTADO, I. Multiple congenital urogenital abnormalities in a Tennessee Walking Horse colt. Equine Vet. Educ., v.21, p.315-318, 2009. 